\title{
Pengamatan Jaringan Lambung Kijing Taiwan (Anodonta woodiana Lea) Yang Terdedah Pestisida Diazinon 60 EC Pada Beberapa Konsentrasi
}

\author{
Listiya Gita Lesmana ${ }^{1}$, Diana Arfiati ${ }^{1}$, Asus Maizar ${ }^{1}$ \\ ${ }^{1}$ Jurusan Manajemen Sumberdaya Perairan, Fakultas Perikanan dan Kelautan, \\ Universitas Brawijaya
}

\begin{abstract}
Abstrak
Jaringan lambung yang diamati berasal dari kijing (Anodonta woodiana) yang terdedah pestisida Diazinon 60 EC selama 2 minggu dengan pemberian dosis yang berbeda, yaitu $3,5 \times 10^{-6} ; 1,75 \times 10^{-6} ; 0,875 \times 10^{-6}$ dan 0 ppm. Kondisi kijing diamati sebelum pemberian pestisida dan setelah 1 minggu dan 2 minggu pendedahan. Irisan lambung dibuat dari sampel 1 dan 2 minggu pendedahan menggunakan pewarnaan $H E$. Analisis histologi lambung kijing menunjukkan bahwa dinding lambung setelah terdedah pestisida akan mengalami kerusakan berupa penebalan dinding (edema), dengan jarak digestive divericula saling berjauhan, silia dalam lambung terlihat menyatu (fusi) dan terjadi pembengkakan silia (hyperplasia). Bahkan setelah pendedahan pestisida selama 2 minggu, dinding lambung makin menebal serta digestive diverticula mengalami pengerutan (atropi) dan pemecahan atau kerusakan sel (nekrosis).
\end{abstract}

Kata Kunci : Anodonta woodiana, Diazinon 60 EC, Kerusakan lambung

\section{Abstract}

Stomach tissue of mussel (Anodonta woodiana) was observed. It was exposured by pesticide Diazinon 60 EC for 2 weeks by different doses: $3,5 \times 10^{-6} ; 1,75 \times 10^{-6} ; 0,875 \times 10^{-6}$ and 0 ppm. Observed tissues are the first condition of mussel or before pestiside, 1 week and 2 weeks of exposure. Stomach slice was made from before, 1 week and 2 weeks exposure by HE colouration. Histology analysis of mussel's stomach show that wall of stomach after pesticide exposure get damages as wall thickening (edema), with apart digestive diverticula distance, silia fusion and swelling (hyperplasia). Even, after for 2 week pesticide exposure, the stomach wall becoming thicker and digestive diverticula also srink (atropy) and necrosis.

Key words: Anodonta woodiana, Diazinon 60 EC, stomach damaging

\section{PENDAHULUAN}

Diazinon merupakan salah satu insektisida golongan organofosfat yang banyak dipakai dalam usaha pertanian untuk mengendalikan hama pada tanaman padi, bunga dan sayuran. Diazinon merupakan racun kontak dan racun sistemik. Senyawa diazinon merupakan thiophosphoric acid ester dengan rumus empirik $\mathrm{C}_{12} \mathrm{H}_{21} \mathrm{~N}_{2} \mathrm{O}_{3} \mathrm{PS}$ dan nama kimia O-Diethyl-O-(2isopropyl-6-methyl-pyrimidine-4-yl). Keracunan Diazinon dapat menimbulkan gejala klinis seperti lemas, depresi, inkoordinasi, hipersalivasi, kekejangan, kelemahan anggota gerak, dispnea, diare, tremor dan kematian. Diazinon yang telah

\footnotetext{
* Alamat korespondensi:

Listiya Gita Lesmana

Email : Lesmana@ub.ac.id

Alamat : Jurusan Manajemen Sumberdaya Perairan, Fakultas Perikanan dan Kelautan, Universitas Brawijaya
}

masuk di dalam tubuh akan menghambat kerja enzim cholinesterase yang ada di dalam darah sehingga peredaran darah yang menuju ke saraf akan terganggu [1]. Transfer pestisida dapat terjadi melalui lima cara, yaitu: adsorpsi, penguapan, aplikasi pestisida yang tidak tepat, limpasan akhir dan rembesan [2]. Pestisida tersebut secara tidak langsung akan masuk ke perairan yang berpotensi menjadi bahan pencemar.

Kehadiran pencemar pada suatu perairan dapat dideteksi dengan beberapa cara yaitu cara kimia, fisika dan biologi. Pendeteksian dengan cara bioiogis biasanya disebut biomonitor. Salah satu hewan yang memenuhi syarat-syarat sebagai biomonitor adalah Kijing Taiwan (Anodonta woodiana). Hewan ini merupakan jenis hewan kerang berbentuk simetri bilateral yang terdiri dari dua keping cangkang cembung, Kijing ini dapat hidup di air tawar, dasar laut, danau, kolam, atau sungai yang banyak 
mengandung zat kapur. Zat kapur ini digunakan untuk membentuk cangkangnya. Kijing ini dapat tumbuh pada kisaran suhu air antara $16-29^{\circ} \mathrm{C}$ dengan oksigen terlarut 3,8-12,5 ppm dan $\mathrm{pH}$ $6,0-7,6$. Untuk dapat tumbuh dengan baik Kijing Taiwan ini dapat mengatur tingkat metabolisme oksigen dengan baik sehingga masih dapat hidup dengan kandungan oksigen dalam air yang berjumlah sedikit [3].

Maka dalam penelitian ini $A$. woodiana dijadikan sebagai hewan uji dan yang diamati adalah bentuk lambung kijing yang telah terdedah pestisida Diazinon 60 EC. Sehingga perlu diketahui bagaimana pengaruh pencemaran pestisida terhadap jaringan lambung Kijing Taiwan. Penelitian ini bertujuan untuk mengetahui kondisi jaringan lambung Kijing Taiwan ( $A$. woodiana) yang hidup pada perairan yang mengandung Diazinon 60 EC pada beberapa konsentrasi.

\section{METODE PENELITIAN}

Materi yang digunakan dalam penelitian ini adalah Kerang $A$. woodiana yang diambil dari Unit Pengelolaan Budidaya Air Tawar (UPBAT) Punten dan parameter perairan yang diukur meliputi suhu, $\mathrm{pH}$ tanah, $\mathrm{pH}$ perairan, oksigen terlarut (DO), dan total bahan organik (TOM). Metode penelitian yang digunakan adalah eksperimen, yaitu dengan memberikan perlakuan dosis pestisida Diazinon 60 EC yang berbeda. Empat kijing dimasukkan ke dalam tiap bak percobaan yang telah berisi air dan sedimen dengan dosis masing-masing bak $3,5 \times 10^{-6}$; $1,75 \times 10^{-6} ; 0,875 \times 10^{-6}$ dan 0 ppm. Pendedahan dilakukan selama 2 minggu. Kondisi kijing diamati pada awal atau sebelum pemberian pestisida, 1 minggu setelah pendedahan dan 2 minggu setelah pendedahan. Selanjutnya bagian lambung kijing diambil dan dibuat irisan jaringan, kemudian diamati menggunakan mikroskop.

\section{HASIL DAN PEMBAHASAN}

Tebal dinding lambung kijing yang tidak mendapat pestisida berkisar antara 1,3-3,3 $\mu \mathrm{m}$ dan digestive diverticula mengelilingi dinding lambung. Hasil pendedahan pestisida Diazinon konsentrasi $0,875 \times 10^{-6} \mathrm{ppm}$ dan $1,75 \times 10^{-6} \mathrm{ppm}$ selama satu minggu menunjukkan lambung kijing mengalami tanda-tanda kerusakan yaitu di sekitar lambung seperti ada lendir yang mulai menutupi hingga terlihat lambung agak menebal (edema) dengan tebal dinding lambung berkisar antara 6,6-12 $\mu \mathrm{m}$ dan 6,6-17,3 $\mu \mathrm{m}$. Silia mengalami fusi dan juga penebalan (hyperplasia) dan digestive diverticula mulai mengalami pembesaran (edema) bila dibandingkan dengan lambung kijing tanpa pemberian pestisida. Sedangkan lambung kijing yang didedah konsentrasi $3,5 \times 10^{-6} \mathrm{ppm}$ pada minggu pertama dinding lambungnya sudah mengalami penebalan (edema) dengan tebal berkisar antara 13,3 - 23,3 $\mu \mathrm{m}$. Silia mengalami hyperplasia dan digestive diverticulanya menyempit (atropi) dan mulai memencar di luar dinding lambung (Gambar 1).

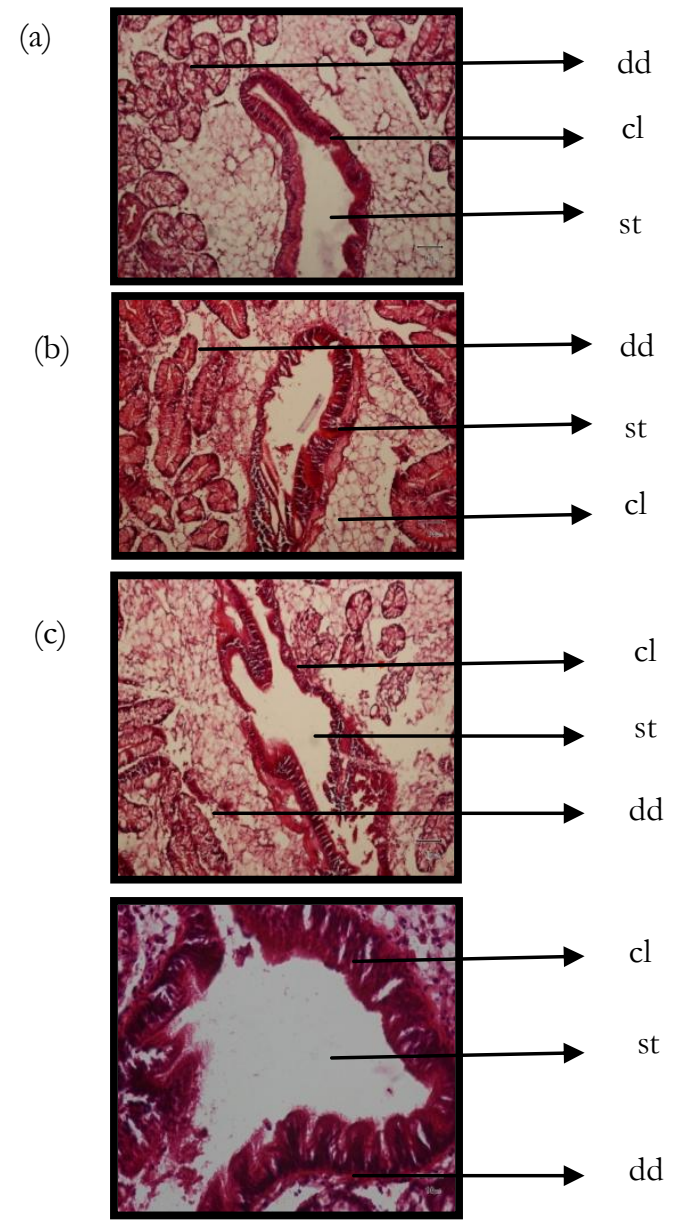

Gambar 1. Irisan melintang lambung kijing minggu pertama konsentrasi $0 \mathrm{ppm}(\mathrm{a}), 0,875 \times 10^{-6} \mathrm{ppm}(\mathrm{b})$,

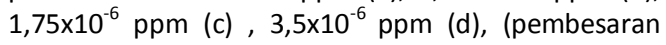
400x, mikroskop Olympus BX 41, kamera Olympus DP 20). st=stomach (lambung), cl=cilia, $d d=$ digestive diverticula

Terjadinya pembesaran dinding lambung dan diverticula diduga disebabkan oleh penumpukan enzim asetikollin akibat adanya penghambatan enzim kolinesterase oleh pencemaran diazinon 60 EC. Pada saat tercemar organofosfat, asetilkolinesteras (AChE) dihambat sehingga terjadi akumulasi asetilkolin (ACh). ACh yang 
ditimbun dalam SSP akan menginduksi tremor, inkoordinasi, dan kejang-kejang. Penghambatan AChE yang diinduksi oleh karbamat dapat pulih dengan cepat, sedangkan pada senyawa organofosfat sulit pulih [4]. Input organofosfat dalam tubuh mengganggu sistem saraf karena munculnya penghambatan oleh enzim asetilkolinesterase [5].

Hasil pengamatan minggu kedua memperlihatkan dinding lambung kijing semakin mengalami penebalan dan silianya juga mengalami kerusakan. Pada konsentrasi $0,875 \times 10^{-6} \mathrm{ppm}$, dinding lambung berukuran 6,6$12 \mu \mathrm{m}$ dan konsentrasi $1,75 \times 10^{-6} \mathrm{ppm}$ menyebabkan dinding lambung berukuran 6,6$17,3 \mu \mathrm{m}$. Bentuk lambung tidak beraturan, arah silia tidak beraturan (fusi) dan digestive diverticula menjauhi dinding lambung dan masih menyebar namun telah mengalami atropi (Gambar 2).

(a)

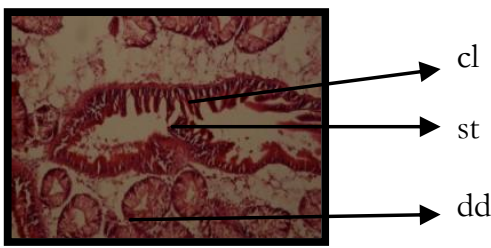

(b)

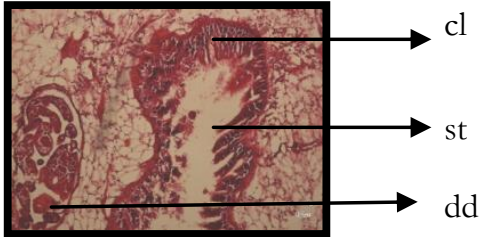

(c)

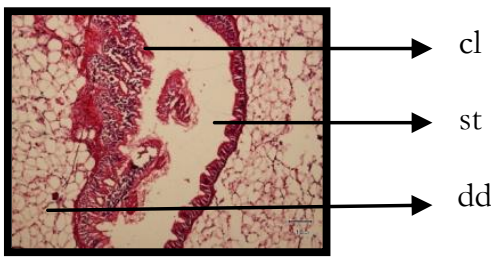

(d)

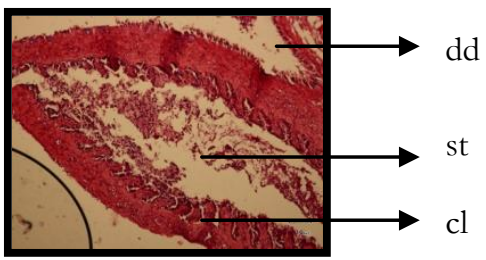

Gambar 2. Irisan melintang lambung kijing hasil pendedahan minggu kedua konsentrasi $0 \mathrm{ppm}(\mathrm{a})$,

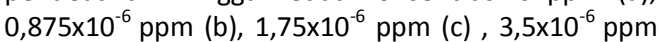
(d) (pembesaran 400x, mikroskop Olympus BX 41, kamera Olympus DP 20). st=stomach (lambung), $\mathrm{cl}=c$ ilia, $\mathrm{dd}=$ digestive diverticula

Sedangkan untuk lambung kijing yang didedah dalam konsentrasi $3,5 \times 10^{-6} \mathrm{ppm}$, penebalan dinding lambung (edema) semakin meningkat, yaitu 10-32 $\mu \mathrm{m}$. Silia juga mengalami penebalan dan pemendekan (hyperplasia) dengan arah yang tidak sama (fusi), sedangkan digestive diverticula menyebar jauh dari dinding lambung serta mengalami atropi dan nekrosis (Gambar 2).

Kerusakan membran sel dapat menghambat masuknya zat-zat ke dalam sel, dan zat-zat dalam sel seperti ion organik, enzim dan asam amino dapat keluar dari sel. Enzim yang keluar dari sel bersama zat-zat tersebut akan menghambat metabolisme sel. Hal tersebut akhirnya akan mengakibatkan terjadinya kematian sel [6].

\section{KESIMPULAN}

Dinding lambung kijing setelah terdedah pestisida akan mengalami beberapa kerusakan, yaitu: pembengkakan (edema); jarak digestive menjauh; silia dalam lambung terlihat menyatu (fusi); dan pembengkakan silia (hyperplasia). Setelah pendedahan pestisida selama dua minggu, dinding lambung makin menebal, digestive diverticula mengalami pengerutan (atropi) dan pemecahan dan nekrosis.

\section{SARAN}

Perlu perhatian dalam pemanfaatan perairan yang mengandung pestisida karena akan merusak jaringan organisme yang hidup di dalamnya.

\section{DAFTAR PUSTAKA}

[1] Raflizar. 2001. Gejala klinis dan patologi anatomi mencit. Jurnal Cermin Dunia Kedokteran 131.

[2] Manuaba, I.B. 2009. Cemaran pestisida Karbamat dalam air danau Buyan Buleleng Bali. Jurusan Kimia, FMIPA, Universitas Udayana. ISSN 1907-9850.

[3] Wilda, G.H. 2003. Uji kapasitas Kijing Taiwan (Anodonta Woodiana) dalam menurunkan kadar polutan pestisida Karbaril pada perairaran tawar. Institut Pertanian Bogor. Oseana XVII (5): 18-23.

[4] Frank, C.L. 1995. Toksikologi dasar (asas, organ sasaran, dan penilaian resiko). Penerbit Universitas Indonesia. Jakarta.

[5] Hassall, K.A. 1982. The chemistry of pesticides. Macmilan Education Ltd. Basingstoke and London.

[6] Pelczar, M.J. dan Chan. 1988. Dasar-Dasar Mikrobiologi (Jilid 2). Universitas Indonesia Press. Jakarta. 